\title{
KETERLIBATAN PESERTA PADA PROSES PELAKSANAAN PELATIHAN SUBKEJURUAN MOBIL DIESEL DI UNIT PELAKSANA TEKNIS PELATIHAN KERJA (UPT-PK) SINGOSARI MALANG
}

\author{
Reskie Wulan Sari, S. Mundzir \\ Universitas Negeri Malang, Jalan Semarang 5 Malang 65145 \\ Email: reskiewulan@yahoo.com
}

\begin{abstract}
The involvement of learner in the training program of mobil diesel is one of factor that will determine the successful of that program. The objective of this research is to know the forms of participant involvement, quality of participant involvement, and factors that influence participant involvement in the training implementation process. This research uses qualitative approach with research type of case study. Data collection conducted by observation, interview, and documentation method. From the research result, it is known that: (1) forms of participant involvement only limited to the learning process; (2) participant involvement divided into active and passive involvement because not all of participant that active in the training; and (3) factor that influence participant involvement is intrinsic and extrinsic factor.
\end{abstract}

Keywords: involvement, training participant

\begin{abstract}
Abstrak: Keterlibatan peserta didik dalam program pelatihan mobil diesel merupakan salah satu faktor yang akan menentukan keberhasilan program tersebut. Tujuan penelitian ini yaitu, mengetahui bentuk-bentuk keterlibatan peserta, kualitas keterlibatan peserta, dan faktorfaktor yang mempengaruhi keterlibatan peserta pada proses pelaksanaan pelatihan. Penelitian ini menggunakan pendekatan kualitataif dengan jenis penelitian studi kasus. Pengumpulan data dilakukan dengan metode observasi, wawancara, dan dokumentasi. Dari hasil penelitian diketahui: (1) bentuk-bentuk keterlibatan peserta hanya terbatas pada proses pembelajaran; (2) keterlibatan peserta dibedakan menjadi keterlibatan aktif dan keterlibatan pasif karena tidak semua peserta giat dalam pelatihan; dan (3) faktor yang mempengaruhi keterlibatan peserta yaitu faktor instrinsik dan faktor ekstrinsik.
\end{abstract}

Kata kunci: keterlibatan, peserta pelatihan

Pelatihan mobil diesel yang diselenggarakan oleh UPT-PK Singosari Malang ini merupakan salah satu upaya agar terciptanya tenaga kerja profesional, inovatif dan produktif yang sesuai dengan perkembangan pasar kerja global, hal tersebut sesuai dengan visi dari UPT-PK Singosari Malang dibawah naungan dinas Tenaga Kerja Transmigrasi dan Kependudukan Provinsi Jawa Timur. Sebuah program pelatihan akan berhasil apabila menggunakan prinsip-prinsip pelatihan. Hal tersebut sesuai dengan prinsip-prinsip pelatihan yang dikemukakan Sudjana, yaitu: (1) berdasarkan kebutuhan belajar (learning needs based); (2) berorientasi pada tujuan kegiatan belajar (learning goals and objectives oriented); (3) berpusat pada peserta (participant centered); dan (4) belajar berdasarkan pengalaman (experiential learning) (Fauzi, 2011). Program pelatihan sebaiknya menggunakan prinsip-prinsip tersebut agar tujuan pelatihan bisa tercapai seperti yang direncanakan sebelumnya.

Berdasarkan prinsip-prinsip pelatihan yang dikemukakan oleh Sudjana, diterangkan bahwa sebuah pelatihan hendaknya diselenggarakan berdasarkan kebutuhan belajar (Fauzi, 2011). Hal ini berarti bahwa peserta didik yang mengikuti jenis pelatihan tertentu selalu dilandasi oleh adanya sebuah kebutuhan terhadap keterampilan tersebut. Tetapi sebuah fenomena menarik terjadi di Unit Pelaksana Teknis Pelatihan Kerja yang seterusnya akan disebut UPT-PK Singosari Malang. Hampir sebagian besar peserta pelatihan mengalami 
kemalasan belajar, hal itu dilihat dari jumlah peserta pelatihan angkatan III Sub Kejuruan Mobil Diesel sebanyak 28 orang, yang masuk tepat waktu setiap harinya rata-rata hanya 3 s.d. 4 orang, yang terlambat 19 s.d. 20 orang, dan yang tidak masuk 5 orang. Kegiatan di kelas seharusnya dimulai pukul 07.30 Waktu Indonesia Barat (WIB), tetapi yang datang tepat waktu sebelum pukul 07.30 WIB hanya 3 s.d. 4 orang saja, sedangkan yang lainya datang pukul 08.00 WIB, bahkan ada yang datang antara pukul 08.30-09.00. Tidak hanya soal kehadiran peserta pelatihan yang tidak disiplin tetapi ketika proses pembelajaran sedang berlangsung, banyak peserta pelatihan yang bermain handphone, bahkan ada yang diam-diam membeli kopi di kantin. Data ini berdasarkan hasil observasi selama seminggu yang dilakukan mulai tanggal 30 September s.d. 4 Oktober 2013 untuk melakukan pendataan presensi secara langsung dan pengamatan selama dua bulan ketika Praktik Pengalaman Lapangan (PPL) di kelas pelatihan Mobil Diesel UPT-PK Singosari Malang.

Fokus sasaran pelatihan mobil diesel di UPTPK Singosari Malang ini adalah siswa lulusan SMA atau SMK sederajat, oleh karena itu pelatihan ini seharusnya menggunakan prinsip-prinsip pembelajaran orang dewasa (andragogi). Hal ini dikarenakan proses belajar orang dewasa berbeda dengan anak sehingga memerlukan perlakuan yang berbeda pula. Sehubungan dengan hal itu maka diperlukan adanya prinsip-prinsip pembelajaran andragogi dalam sebuah pelatihan agar peserta didik merasa dihargai dan nyaman dengan proses pelatihan sehingga terjadilah keterlibatan yang baik oleh peserta didik. Tidak bisa dipungkiri bahwa keterlibatan peserta pelatihan dalam proses pembelajaran ikut menentukan keberhasilan suatu program pelatihan. Seperti yang diungkapkan Knowles, bahwa orang dewasa merasa termotivasi untuk berpartisipasi dalam suatu kegiatan belajar apabila teknik dan metode pembelajaran menggunakan pendekatan yang bersifat andragogi (Riwu, 2007). Peserta pelatihan orang dewasa akan terlibat aktif dalam pembelajaran apabila diperlakukan oleh instruktur layaknya orang dewasa dan bukan anak-anak seperti di sekolah.

Secara toeritik bentuk keterlibatan peserta pada proses pelaksanaan pelatihan yaitu interkasi kegiatan pembelajaran antara peserta dengan sumber belajar maupun antar peserta dilakukan melalui hubungan horisontal. Pendekatan kegiatan belajar berpusat pada peserta bukan sumber belajar, dalam arti penyusunan bahan belajar dan penentuan langkah-langkah kegiatan belajar dilakukan bersama oleh peserta dengan sumber belajar atau dengan bimbingan sumber belajar, peranan sumber belajar sebagai fasilitator yaitu membantu peserta dalam melakukan kegiatan pembelajaran (Fauzi, 2011). Oleh sebab itu, antara peserta didik dengan lembaga sebaiknya saling bekerjasama untuk menyusun materi belajar dan langkah-langkah kegiatan belajar agar tujuan pelatiha yaitu untuk meningkatkan keterampilan, pengetahuan, dan sikap bisa tercapai. Berdasarkan hal-hal tersebut seharusnya dalam sebuah program pelatihan terjadi keterlibatan yang baik dan aktif oleh peserta didik, namun fenomena yang teramati menunjukkan masih ada peserta didik yang terlibat pasif selama proses pelaksanaan pelatihan mobil diesel berlangsung.

\section{METODE}

Penelitian ini dilakukan di UPT-PK Singosari Malang. Pendekatan yang digunakan dalam penelitian ini adalah penelitian kualitatif dengan jenis penelitian Studi Kasus. Jenis penelitian ini dipilih karena peneliti mengeksplorasi sebuah sistem dari sebuah kasus melalui pengumpulan data yang rinci dan mendalam dan mencakup multi sumber informasi yang kaya dengan konteks. Kehadiran peneliti dilapangan adalah sebagai instrumen kunci yang merencanakan, melaksanakan dan menganalisa data penelitian. Data yang terkumpul dari berbagai sumber dan bebrapa teknik pengumpulan data. Peneliti melakukan observasi mulai dari kegiatan pembelajaran di kelas pelatihan sampai aktifitas yang ada di kantor untuk mencari informasi yang dibutuhkan sesuai dengan penelitian, melakukan wawancara berdasarkan pedoman wawancara yang telah disusun kepada pihak-pihak yang terkait dengan penelitian, dan dokumentasi dari foto-foto kegiatan, arsip-arsip berkaitan dengan penelitian, profil lembaga, data peserta pelatihan, matrik program pelatihan, jadwal pelatihan, presensi peserta pelatihan dan merekam aktivitas pelatihan.

Subyek penelitian ini adalah peserta pelatihan mobil diesel angkatan III jalur swadana dan 
prakerin. Dalam pengumpulan data melalui teknik wawancara mendalam peneliti menentukan jumlah informan dan memiliki kriteria informan penelitian yaitu yang mengetahui proses pelatihan dan mengetahui informasi berkaitan pelatihan mobil diesel. Informan dalam penelitian ini adalah peserta pelatihan mobil diesel empat orang, instruktur mobil diesel satu orang, dan KASI PS (pelatihan dan sertifikasi).

Analisis data yang digunakan mencakup tiga komponen yang saling berkaitan menurut Miles dan Huberman, yaitu: (1) reduksi data; (2) penyajian data; dan (3) penarikan kesimpulan (Sugiyono, 2011). Untuk mengecek keabsahan data, peneliti menggunakan kriteria kredibilitas yang digunakan untuk membuktikan bahwa data atau informasi yang ditemukan di lapangan benar dan untuk menjamin keabsahan data. Validasi dilakukan dengan trianggulasi (Moedzakir, 2010). Kegiatanya terdiri dari trianggulasi metode, trianggulasi sumber, dan trianggulasi waktu.

\section{HASIL}

Hasil penelitian menunjukkan bahwa keterlibatan peserta pelatihan pada proses pelaksanaan pelatihan adalah sebagai berikut. Bentuk-bentuk keterlibatan peserta yang dilakukan di awal proses pembelajaran yaitu mengikuti apel pagi, membuka pintu kelas, menghidupkan lampu, mempersiapkan alat praktik, membereskan alat praktik, menyapu area bengkel atau ruang praktik, menyapu halaman ruang praktik. Bentuk-bentuk keterlibatan peserta pada saat pelaksanaan pembelajaran yaitu, diskusi tentang masalah perbaikan mesin yang belum bisa diselesaikan, mengajari teman yang belum bisa, ngobrol, menghidupkan mesin mobil Taft, merangkai kelistrikan, menganalisa baterai dan mengecek baterai tersebut, mendengarkan teori yang di jelaskan instruktur, bertanya materi yang belum di pahami, menjalankan praktik sesuai perintah instruktur tetapi terkadang sambil bermain handphone dan begurau dengan temanteman sekelompok, menunggu giliran praktik sambil bermain handphone, konsultasi dengan instruktur berkaitan dengan materi yang belum paham, memperhatikan materi yang dijelaskan oleh instruktur, terkadang tidur di kelas apabila sudah jenuh, mencari materinya sendiri, tanya jawab materi yang belum tahu, saling mengejek dengan kelompok yang lain, berbagi cerita dan pengalaman dengan instruktur, banyak bercanda di akhir-akhir pelajaran.

Selanjutnya yaitu bentuk keterlibatan peserta didik yang dilakukan setelah pelaksanaan pembelajaran yaitu membersihkan dan menata alat praktik pada tempatnya, membersihkan ruangan praktik, merapikan ruangan yang ada di dalam, mematikan lampu, berjabat tangan dengan instruktur lalu pulang, terkadang mengikuti jam tambahan memperbaiki mobil yang rusak, dan membantu instruktur mengajar PVTI di kelas lain. Kualitas keterlibatan dibagi menjadi dua yaitu kualitas keterlibatan aktif dan kualitas keterlibatan pasif. Kualitas keterlibatan aktif adalah bentuk keterlibatan peserta pelatihan yang rajin dan giat selama mengikuti pelatihan, sedangkan keterlibatan pasif adalah bentuk keterlibatan yang hanya diam mendengarkan dan tidak giat selama mengikuti proses pelatihan. Kualitas keterlibatan aktif yaitu, mengikuti apel pagi, membuka pintu kelas, menghidupkan lampu, mempersiapkan alat praktik, membereskan alat praktik, menyapu area bengkel atau ruang praktik, menyapu halaman ruang praktik, menjalankan praktik sesuai perintah instruktur, bertanya materi yang belum di pahami, berbagi cerita dan pengalaman dengan instruktur, diskusi tentang masalah perbaikan mesin yang belum bisa diselesaikan, mencari materinya sendiri, mengajari teman yang belum bisa, menghidupkan mesin mobil Taft, merangkai kelistrikan, menganalisa baterai dan mengecek baterai tersebut, tidak pernah membolos, konsultasi dengan instruktur tentang materi yang belum paham, ikut jam tambahan membetulkan mobil-mobil yang rusak, merapikan alat praktik dan membersihkan ruangan praktik ketika akan pulang, membantu instruktur mengajar PVTI di kelas lain, sebelum pulang membersihkan ruangan terlebih dahulu dan membereskan peralatan kerja serta berjabat tangan dengan instruktur untuk pamit pulang.

Dari hasil paparan data yang diperoleh dari peserta didik bisa disimpulkan yang termasuk dalam keterlibatan pasif yaitu, mendengarkan teori yang dijelaskan oleh instruktur, memperhatikan materi yang dijelaskan instruktur, ngobrol, saling mengejek dengan kelompok yang lain, banyak bercanda di akhir pembelajaran, tidur di 
kelas apabila sudah jenuh, bermain handphone dan begurau dengan teman-teman sekelompok, menunggu giliran praktek sambil bermain handphone. Faktor-faktor yang mempengaruhi keterlibatan peserta pada proses pelaksanaan pelatihan mobil diesel di UPT-PK Singosari Malang, yaitu: (1) faktor instrinsik atau faktor dari dalam diri meliputi motivasi peserta didik mengikuti pelatihan; dan (2) faktor ekstrinsik yaitu faktor dari luar meliputi, cara instruktur mengajar, cara instruktur memperlakukan peserta didik, metode yang digunakan instruktur dalam mengajar, materi yang diajarkan dalam pelatihan, alasanalasan peserta didik kurang tertarik berpartisipasi aktif, dan kebijakan-kebijakan lembaga. Motivasi peserta didik mengikuti pelatihan mobil diesel ini yaitu karena mengikuti Sudarsa S.Pd, instruktur mobil diesel yang memang ada ikatan saudara tetapi lama-lama merasa nyaman, agar lebih mudah mencari pekerjaan, ingin meneruskan dan mengembangkan ilmu sesuai jurusan ketika di SMK, ingin memperdalam ilmu tentang mobil diesel.

Cara instruktur mengajar dalam proses pembelajaran selama ini menurut peserta didik yaitu, dalam menjelaskan teori maupun praktek mendetail dan mudah dipahami, namun ada salah satu instruktur yang kurang disiplin waktu. Perduli dan tanggap apabila ada peserta didik yang bertanya. Cara instruktur memperlakukan peserta didik yaitu, diperlakukan seperti anak sendiri, perduli dengan peserta didik, mendidik, mendorong peserta didik untuk mentaati tata tertib yang ditentukan, seperti pengajar-pengajar umumnya. Metode yang digunakan instruktur mengajar menurut peserta didik yaitu, belum sesuai karena materinya belum semua dipelajari, sudah sesuai karena berbeda dengan metode yang digunakan di sekolah, tidak sesuai karena prakteknya tidak sesuai prosedur. Materi yang ajarkan dalam pelatihan mobil diesel menurut peserta didik yaitu, materinya belum semua disampaikan karena jam latihan yang kurang, ada yang berpendapat materinya sudah sesuai seperti yang diharapkan ketika masuk UPTPK Singosari, cukup baik dan sesuai.

Alasan-alasan peserta didik kurang tertarik berpartisipasi aktifdalam pembelajaran diantaranya yaitu, ruangan teori tidak nyaman dan panas, ketika praktek harus menuggu giliran sehingga bosan, kondisi ruangan berdebu, alat praktek berantakan dan tidak teratur, sering ditinggal instruktur sehingga tidak ada yang mengawasi, salah satu instruktur tidak disiplin. Kebijakan-kebijakan yang di buat oleh lembaga tentang monitoring dan evaluasi pelatihan dalam mendukung pelaksanaan proses pelatihan diantaranya yaitu, monitoring dan evaluasi yang dilakukan oleh bagian Pelatihan dan sertifikasi (PS) tidak terstruktur sehingga tidak dilakukan secara teratur, pengecekan di kelas dilakukan kadang-kadang dan jika ada yang tidak disiplin akan di tegur dan dipanggil ke bagian Pelatihan dan sertifikasi, adapun strategi dan metode yang digunakan dalam monitoring dan evaluasi menggunakan angket yang dibagikan kepada peserta didik untuk menilai kinerja instruktur dan pelaksanaan program pelatihan.

\section{PEMBAHASAN}

Salah satu komponen penting dalam program pelatihan yang ikut menentukan keberhasilan sebuah pelatihan adalah peserta didik. Segala bentuk atau wujud keterlibatan peserta didik dalam mengikuti pelaksanaan program pelatihan akan menentukan keberhasilan pelatihan itu sendiri. Asumsi tersebut dikuatkan oleh Kaplan, bahwa pelibatan peserta belajar (warga belajar) dalam segala gerak proses pembelajaran, akan membantu mempercepat penguatan bagi terjadinya perubahan atas diri mereka juga atas dasar kemauan diri mereka, serta membantu perkembangan di masa yang akan datang (Kamil, 2010). Keterlibatan peserta pelatihan dalam segala proses pembelajaran pelatihanmobildieselakan membantumempercepat penguatan perubahan terutama keterampilan yang dimilikinya. Berdasarkan hasil penelitian yang telah disebutkan pada point sebelumnya dapat diketahui bentuk-bentuk keterlibatan peserta pelatihan mobil diesel di UPT-PK Singosari selama proses pelatihan secara keseluruhan berdasarkan kondisi nyata dilapangan. Sedangkan Fauzi (2011) menyatakan bahwa partisipasi dalam tahap pelaksanaan yaitu interaksi kegiatan pembelajaran antara peserta dengan sumber belajar maupun antar peserta dilakukan melalui hubungan horisontal. Pendekatan kegiatan belajar berpusat pada peserta bukan sumber belajar, dalam arti penyusunan bahan belajar dan penentuan langkah-langkah 
kegiatan belajar dilakukan bersama oleh peserta dengan sumber belajar atau dengan bimbingan sumber belajar.

Berdasarkan hasil temuan lapangan dengan teori, menyebutkan bahwa bentuk keterlibatan peserta didik selama proses pelaksanaan pelatihan selama ini terbatas pada proses pembelajaran saja, peserta didik tidak ikut terlibat dalam proses penyusunan bahan belajar dan penentuan langkah-langkah kegiatan belajar. Sehingga bentuk keterlibatan peserta didik hanya tinggal menjalankan sesuai arahan instruktur karena semua tata tertib dan materi pelatihan sudah disusun dan ditentukan oleh lembaga. Tidak semua bentuk keterlibatan peserta pada proses pelaksanaan pelatihan mobil diesel tersebut berkualitas baik. Kualitas yang dalam kamus besar bahasa Indonesia artinya adalah tingkat baik buruknya sesuatu, derajat atau taraf (kepandaian, kecakapan,keaktifan), atau disebut mutu. Walaupun setiap peserta pelatihan terlibat dalam proses pelatihan akan tetapi kualitas keterlibatan itu berbeda-beda. Untuk itu kualitas keterlibatan disini bisa dilihat dari bentuk keterlibatan peserta didik yang aktif dan yang pasif seperti yang telah disebutkan pada hasil penelitian. Adapun keuntungan partisipasi peserta didik menurut Mangkunegara manyatakan beberapa hasil penelitian dapat disimpulkan bahwa ada beberapa keuntungan yang dapat ditarik dari partisipasi warga belajar/peserta didik dalam pengelolaan pembelajaran adalah: (1) hasil belajar menjadi lebih tinggi; (2) kualitas belajar menjadi lebih baik; (3) motivasi berprestasi tinggi; (4) adanya penerimaan perasaan karena keterlibatan emosi dan mental selama proses pembelajaran; (5) harga diri warga belajar menjadi lebih tinggi; (6) meningkatnya kepuasan kerja dan belajar (Kamil, 2010).

Keterlibatan aktif peserta pelatihan mobil diesel akan memberikan banyak keuntungan terutama untuk kualitas hasil belajar peserta didik itu sendiri. Hal ini dikarenakan peserta didik yang aktif akan membuat hasil belajar menjadi lebih tinggi, kualitas belajar menjadi lebih baik, dan motivasi berprestasi tinggi. Sedangkan keterlibatan pasif peserta pelatihhan mobil diesel tidak akan memberikan keuntungan terhadap kualitas belajarnya karena peserta didik tidak giat berusaha dalam pembelajaran selama proses pelatihan. Selanjutnya faktor-faktor yang mempengaruhi keterlibatan peserta pelatihan diantaranya adalah motivasi, hal tersebut tidak terlepas dari teori kebutuhan Maslow dimana orang akan tertarik untuk memenuhi kebutuhan yang lebih tinggi/ aktualisasi diri seperti mengikuti pelatihan mobil diesel apabila keempat kebutuhan yang lainya seperti fisiologis, rasa aman, kasih sayang, dan harga diri sudah terpenuhi. Hal ini didukung dengan teori Maslow, bahwa manusia mempunyai lima tingkatan kebutuhan, yaitu: (1) kebutuhan fisiologikal: rasa lapar, haus, istirahat, sex; (2) kebutuhan rasa aman: tidak dalam arti fisik semata tetapi juga mental, psikologi, intelektual; (3) kebutuhan akan kasih sayang; (4) kebutuhan harga diri; dan (5) aktualisasi diri (Yudhawati dan Haryanto, 2011).

Dikaitkan dengan teori yang dikemukakan oleh Maslow, menjelaskan bahwa tingkatan tertinggi adalah aktualisasi diri, yaitu tersedianya kesempatan bagi seseorang untuk mengembangkan potensi yang terdapat dalam dirinya sehingga berubah menjadi kemampuan nyata (Yudhawati dan Haryanto, 2011). Hal ini sesuai dengan motivasi peserta didik mengikuti pelatihan mobil diesel karena ingin mengembangkan ilmu yang didapat ketika di SMK, dan ingin memperdalam ilmu mobil diesel, dari kemampuan yang dimilikinya setelah mengikuti pelatihan mobil diesel tersebut maka peserta didik yakin akan lebih mudah mendapatkan pekerjaan dengan potensi yang dimilikinya. Selanjutnya adalah cara instruktur mengajar, peneliti memperoleh data tentang cara instruktur sub kejuruan mobil diesel mengajar selama ini yaitu dalam menjelaskan teori maupun praktek mendetail dan mudah dipahami, namun ada salah satu instruktur yang kurang disiplin waktu, instruktur perduli dan tanggap apabila ada peserta didik yang bertanya. Hal tersebut juga dikemukakan oleh Atmodiwirio, bahwa unsurunsur yang dinilai fasilitator adalah penguasaan materi, sistematika penyajian, kemampuan menyajikan materi, ketepatan fasilitator waktu hadir di kelas, penggunaan metode mengajar dan alat bantu mengajar, sikap dan perilaku, cara fasilitator menjawab pertanyaan dari peserta, penggunaan bahasa, pemberian motivasi belajar kepada peserta, pencapaian tujuan pembelajaran, daya simpatik (Fitria, 2013). 
Berdasarkan teori yang dikemukakan tersebut, bahwa seorang instruktur sendiri memang harus memiliki kemampuan menyajikan materi baik secara teori maupun praktek sehingga peserta didik mudah memahami, begitupun kewajiban instruktur menjawab pertanyaan peserta didik juga merupakan tanggungjawabnya. Tidak hanya itu, ketepatan instruktur waktu hadir di kelas juga hal penting yang seharusnya dipahami oleh instruktur akan tetapi salah satu instruktur mobil diesel UPTPK Singosari ternyata ada yang kurang disiplin waktu. Hal ini menunjukkan kurang terjalin kerjasama yang baik antar instruktur. Kemudian cara instruktur memperlakukan peserta, seorang instruktur harus memiliki kompetensi yang baik dalam mengelola pembelajaran agar kondusif. Seperti yang dilakukan oleh instruktur sub kejuruan mobil diesel di UPT-PK Singosari terhadap peserta didiknya sehingga peserta didik merasa dekat. Hal ini di dukung oleh pendapat Srinivasan, kecakapan yang dibutuhkan oleh seorang instruktur agar dapat berhasil melaksanakan program yaitu: (1) memahami dengan baik pembelajaran orang dewasa; (2) memahami hambatan-hambatan sosial budaya; (3) kecakapan berhubungan dengan peserta didik orang dewasa dengan kasih sayang, hormat, dan optimisme; (4) memiliki gambaran yang jelas tentang peranan pendidikan yang sedang dilaksanakan; dan (5) cakap menciptakan suasana yang sangat kondusif bagi kegiatan belajar yang santai (Marzuki, 2010).

Seorang instruktur pelatihan diharapkan memilikikecakapan dalam mengelolapembelajaran khususnya pendidikan orang dewasa, karena peserta pelatihan mobil diesel adalah orang dewasa sehingga dalam pembelajarannya menggunakan teknik-teknik tersendiri. Tetapi berdasarkan temuan penelitian, walaupun instruktur tidak mengerti tentang pendidikan orang dewasa tapi instruktur cukup baik dalam membangun suasana pelatihan dengan perlakuan yang tepat kepada peserta didik sehingga peserta didik merasa nyaman dengan cara instruktur memperlakukan. Dalam proses pelatihan, metode merupakan unsur yang dapat menunjang pelatihan lebih efektif dan efisien. Hal ini didukung Fauzi (2011) yang menyebutkan terdapat beberapa hal yang perlu diperhatikan sehubungan dengan implikasi aspek psikologis orang dewasa terhadap pelatihan, yaitu metode pembelajaran harus dapat memberikan kesempatan mendengar, berbicara, melihat dan mengerjakan, karena akan lebih efektif bila belajar dengan cara mengalami, bukan hanya diceramahi atau digurui untuk melakukanya.

Dari hasil penelitian metode pelatihan yang digunakan oleh instruktur sudah berdasarkan standar dari UPT-PK Singosari dan sesuai dengan ketentuan BNSP (badan nasional standar pendidikan) sehingga peserta didik tidak dilibatkan dalam penentuan langkah-langkah pembelajaran. Sehingga peserta pelatihan tidak bisa memberikan usulan metode sesuai yang dibutuhkanya karena metode sudah disusun oleh lembaga jadi mau atau tidak mau, peserta pelatihan harus menjalankan sesuai ketentuan dari lembaga. Selanjutnya yaitu kesesuaian materi yang diajarkan di pelatihan mobil diesel UPT-PK Singosari adalah salah satu faktor peserta didik memilih pelatihan mobil diesel. Hal ini sesuai dengan Knowles, orang dewasa akan turut serta dalam suatu kegiatan belajar apabila bidang-bidang yang dipelajari berkaitan dengan pemecahan masalah yang sedang dihadapi (Riwu, 2007). Oleh karena itu, seseorang mengikuti pelatihan dikarenakan merasa membutuhkan keterampilan sesuai materi yang diajarkan oleh instruktur. Materi yang diajarkan oleh instruktur di pelatihan mobil diesel UPT-PK Singosari adalah materi yang sudah ditentukan sesuai standar dari Badan Standar Nasional Pendidikan (BSNP), sehingga pesrta didik tidak bisa terlibat dalam penyusunan materi pelatihan.

Tidak hanya materi saja tetapi jumlah jam latihan mobil diesel juga sudah ditentukan oleh lembaga yaitu 480 jam latihan. Sehingga peserta didik hanya tinggal menjalani pelatihan sesuai arahan instruktur. Sedangkan menurut Marzuki (2010) menjelaskan dalam pengorganisasian materi belajar, seharusnya: peserta dilibatkan dalam merencanakan tujuan dan materi belajar, peserta didik dilibatkan dalam menentukan sistematika kegiatan belajar dengan cara menawarkan program dan kegiatan belajar, terbuka kesempatan untuk mengganti materi pelajaran pada saat tertentu sesuai kesepakatan dengan peserta. Dalam penyeleksian materi belajar, materi hendaknya: bermanfaat dan sesuai dengan kebutuhan peserta, sesuai dengan kemampuan dan kecakapan peserta, berhubungan dengan masa lalu peserta. Agar materi 
dalam sebuah pelatihan bisa memenuhi kebutuhan peserta didik, seharusnya peserta didik dilibatkan dalam penyusunan materi. Tetapi yang terjadi selama ini peserta didik tidak pernah diikutkan dalam penyusunan materi karena materi sudah ada standarnya sendiri dari BSNP.

Alasan-alasan peserta didik kurang tertarik berpartisipasi aktif dalam pembelajaran diantaranya yaitu, ruangan teori tidak nyaman dan panas, ketika praktek harus menunggu giliran sehingga bosan, kondisi ruangan berdebu, alat praktek berantakan dan tidak teratur, sering ditinggal instruktur sehingga tidak ada yang mengawasi, salah satu instruktur tidak disiplin. Permasalahan seperti ini dibenarkan oleh kepala seksi pelatihan dan sertifikasi (KASI PS) UPT-PK Singosari bahwa kondisi ruangan belajar memang panas dan tidak nyaman. Padahal seharusnya peserta didik mendapatkan fasilitas yang memadai agar tercipta suasana belajar yang kondusif. Hal ini didukung oleh Lewin secara tegas menyatakan lingkungan memberikan pengalaman dan mengembangkan kepribadian warga belajar (Kamil, 2010). Selain itu, kenyamanan peserta didik juga harus diperhatikan, Fauzi (2011) menyebutkan kenyamanan ini ditandai dengan adanya hal: (1) ruang pertemuan memiliki penerangan yang memadai dan sirkulasi udara segar; (2) lokasi ruangan tidak merupakan tempat lalulintas orang banyak atau tidak terlalu banyak dilewati orang; dan (3) ruangan sesuai dengan jumlah peserta sehingga ruang gerak peserta tidak terhambat.

Kondisi ruangan pembelajaran seharusnya membuat peserta pelatihan nayaman sehingga proses belajar pembelajaran akan kondusif. Tetapi temuan dilapangan menunjukkan bahwa kondisi ruangan panas dan berdebu sehingga peserta pelatihan merasa tidak nyaman selama proses pembelajaran berlangsung. Tidak hanya kondisi ruangan kelas saja yang menjadi alasan namun seringnya ditinggal instruktur sehingga merasa tidak ada yang mengawasi, salah satu instruktur ada yang tidak disiplin dan timbul rasa bosan ketika menunggu giliran praktek merupakan faktor yang jelas mempengaruhi partisipasi peserta didik dalam proses pembelajaran. Dengan jumlah instruktur yang tidak sesuai dengan jumlah peserta didik dan banyaknya jumlah materi pelatihan yang diajarkan maka instruktur harus bekerja keras agar bisa terciptanya suasana yang kondusif. Hal tersebut diperkuat oleh Fauzi (2011), jumlah fasilitator tergantung pada materi yang akan disampaikan. Dalam hal ini harus dihindari penggunaan fasilitator tunggal karena disampig fasilitator harus terus-menerus mendampingi peserta, juga dikhawatirkan peserta akan bosan dengan gaya pembelajaran yang hanya dilakukan satu orang.

Jumlah instruktur dalam pelatihan harus disesuaikan dengan jumlah peserta didik, dengan begitu maka instruktur akan bisa memantau perkembangan peserta didik dengan lebih maksimal. Program pelatihan mobil diesel selama ini hanya memiliki 2 instruktur sedangkan jumlah peserta pelatihan dalam 1 angkatan ratarata 20 anak, sedangkan dalam sekali program pelatihan biasanya ada 3 angkatan. Oleh karena itu, berdasarkan temuan penelitian yang menyebutkan bahwa peserta didik merasa kurang diawasi/ kurang dipantau dalam menjalankan pembelajaran karena kurangnya tenaga instruktur. Sehingga proses pembelajaran kurang maksimal. Kebijakan-kebijakan yang di buat oleh UPTPK Singosari tentang monitoring dan evaluasi pelatihan dalam mendukung pelaksanaan proses pelatihan diantaranya dalam hal ini adalah bagian pelatihan dan sertifikasi (PS) yaitu, monitoring dan evaluasi yang dilakukan oleh bagian Pelatihan dan sertifikasi (PS) tidak terstruktur sehingga tidak dilakukan secara teratur, pengecekan di kelas dilakukan kadang-kadang dan jika ada yang tidak disiplin hanya akan di tegur dan dipanggil ke bagian Pelatihan dan sertifikasi, adapun strategi dan metode yang digunakan dalam monitoring dan evaluasi menggunakan angket yang dibagikan kepada peserta didik untuk menilai kinerja instruktur dan pelaksanaan program pelatihan.

Kegiatan monitoring dan evaluasi merupakan dua hal penting yang akan mempengaruhi keberhasilan suatu program pelatihan. Suherman menyatakan monitoring dapat diartikan sebagai suatu kegiatan untuk mengikuti perkembangan suatu pelatihan, yang dilakukan secara mantap dan teratur serta terus menerus (Fauzi, 2011). Berdasarkan pernyataan tersebut seharusnya kegiatan monitoring dilakukan secara teratur dan terus-menerus untuk mengetahui perkembangan operasional program pelatihan. Tetapi kenyataan di pelatihan mobil diesel UPT-PK Singosari, kegiatan 
monotoring dilakukan dengan tidak terstruktur. Sudjana menyatakan evaluasi atau penilaian dapat didefinisikan sebagai kegiatan sistematis untuk mengumpulkan, mengolah dan menyajikan data (informasi) yang diperlukan sebagai bahan masukan untuk mengambil keputusan (Fauzi, 2011). Berdasarkan penjelasan tersebut bisa dikatakan evaluasi adalah kegiatan yang sistematis yaitu dilakukan dengan prosedur tertentu yang tertib, diselenggarakan secara terus menerus dan berkala. Hal ini dilakukan untuk mengetahui tingkat kemajuan pelatihan dari segi strateginya. Seperti kegiatan monitoring yang telah dibahas sebelumnya, bahwa evaluasi juga dilakukan secara tidak tertib dan dilakukan kadang-kadang. Hal ini menunjukan bahwa kegiatan monitoring dan evaluasi yang dilakukan oleh lembaga UPT-PK Singosari ini kurang sesuai dengan prosedur.

\section{SIMPULAN DAN SARAN}

\section{Simpulan}

Berdasarkan temuan penelitian yang dikaitkan dengan teori menyebutkan bahwa bentuk keterlibatan peserta didik selama proses pelaksanaan pelatihan mobil diesel terbatas pada proses pembelajaran saja. Peserta didik tidak ikut terlibat dalam proses penyusunan bahan belajar dan penentuan langkah-langkah kegiatan belajar. Sehingga bentuk keterlibatan peserta didik hanya tinggal menjalankan sesuai arahan instruktur karena semua langkah kegiatan pembelajaran dan materi pelatihan sudah disusun dan ditentukan oleh lembaga. Keterlibatan aktif peserta pelatihan mobil diesel akan memberikan banyak keuntungan terutama untuk kualitas hasil belajar peserta didik itu sendiri. Hal ini dikarenakan peserta didik yang aktif akan membuat hasil belajar menjadi lebih tinggi, kualitas belajar menjadi lebih baik, dan motivasi berprestasi tinggi.

Sedangkan keterlibatan pasif peserta pelatihhan mobil diesel tidak akan memberikan keuntungan terhadap kualitas belajarnya karena peserta didik tidak giat berusaha dalam pembelajaran selama proses pelatihan. Faktor yang paling mempengaruhi keterlibatan peserta pelatihan mobil diesel adalah dari cara instruktur mengajar dalam pelatihan karena kemampuan instruktur menentukan suasana pembelajaran dapat mempengaruhi kualitas hasil pelatihan. Selain itu, metode yang digunakan instruktur sudah melibatkan peserta supaya aktif dalam pembelajaran, materi yang diajarkan dalam pelatihan mobil diesel sudah ditentukan oleh UPT-PK sehingga peserta pelatihan hanya tinggal mengikuti sesuai ketentuan dan tidak bisa terlibat dalam penyusunan.

\section{Saran}

Berdasarkan paparan data, temuan penelitian, dan pembahasan maka dapat dikemukakan beberapa saran sebagai berikut. Untuk bentuk keterlibatan peserta pada proses pelaksanaan pelatihan hanya terbatas pada proses pembelajaran saja sehingga diharapkan lembaga UPT-PK dan instruktur mampu melibatkan peserta pelatihan dalam penyusunan bahan belajar dan penentuan langkahlangkah kegiatan belajar secara aktif agar tujuan pelatihan bisa tercapai dengan baik. Untuk kualitas keterlibatan peserta pada proses pelaksanaan pelatihan masih banyak peserta pelatihan yang pasif sehingga instruktur diharapkan mampu meningkatkan kualitas keterlibatan aktif peserta pelatihan agar hasil belajar menjadi lebih tinggi, kualitas belajar menjadi lebih baik, dan motivasi berprestasi tinggi. Instruktur dan lembaga UPTPK Singosari diharapkan menggunakan prinsipprinsip pelatihan dan prinsip andragogi dalam pelaksanaan proses pelatihan supaya metode yang digunakan dalam pelatihan sesuai dengan kondisi peserta pelatihan, materi yang diajarkan sesuai dengan kebutuhan belajar peserta pelatihan, cara instruktur mengajar dan memperlakukan peserta pelatihan tidak seperti guru tehadap muridnya tetapi saling menghargai, menghargai, dan saling mempercayai.

\section{DAFTAR RUJUKAN}

Moedzakir, D. 2010. Desain dan Model Penelitian Kualitatif (Biografi, Fenomenologi, Teori Grounded, Etnografi, dan Studi Kasus). Malang: Fakultas Ilmu Pendidikan Universitas Negeri Malang.

Fauzi, I. K. A. 2011. Mengelola Pelatihan Partisipatif. Bandung: Alfabeta.

Fitria, L. 2013. Pelaksanaan Pendidikan \& Pelatihan (DIKLAT) Pengelola Rumah Pintar 
(RUMPIN) (Studi Kasus pada Seksi Fasilitasi Sumber Daya BP-PAUDNI Regional II Surabaya). Skripsi tidak diterbitkan. Malang: Fakultas Ilmu Pendidikan Universitas Negeri Malang.

Kamil, M. 2010. Model Pendidikan dan Pelatihan (Konsep dan Aplikasi). Bandung: Alfabeta.

Marzuki, Saleh. 2010. Pendidikan Nonformal. Bandung: Rosdakarya.

Riwu, R. 2007. Partisipasi Kaum Ibu dalam Kegiatan Pendidikan Bina Keluarga Balita (BKB). Jurnal Pendidikan Nonformal, 1(1): 45-55.
Sugiyono. 2011. Metode Penelitian Kuantitatif Kualitataif dan R\&D. Bandung: Alfabeta.

Universitas Negeri Malang. 2010. Pedoman Penulisan Karya Ilmiah; Skripsi, Tesis, Desertasi, Artikel, Makalah, Laporan Penelitian. Malang: Universitas Negeri Malang.

Yudhawati, R., \& Haryanto, D. 2011. Teori-teori Dasar Psikologi Pendidikan. Jakarta: PT Prestasi Pustakaraya. 